\title{
UNA EMPRESA OLVIDADA DEL PRIMER GÓTICO HISPANO: LA FACHADA DE LA SALA CAPITULAR DE LA CATEDRAL DE LEÓN *
}

\author{
POR \\ ROCÍO SÁNCHEZ AMEIJEIRAS \\ Universidad de Santiago de Compostela
}

\begin{abstract}
A group of six figural slabs, representing a typical cloister program (Christ, Mary, Saint Peter dressed in monastic habit, Saint Paul and two leonese saint), reinstalled at the Museum of Leon cathedral can be dated at around 1200 and atributed to sculptors trained in first gothic French models. Both iconography and format let suppose that the figures' original disposition was in the portal of the chapter house. Unfortunately only written documentation remains about another decorated portal in the same cloister, that of the refectorium.
\end{abstract}

A finales del siglo Xvi el deán de León Fr. Athanasio de Lobera atribuía al obispo Manrique de Lara, que rigió la diócesis entre 1181 y 1205, la construcción de un claustro en la catedral, para justificar el discutido pasaje de la Cronica de España de Lucas de Tuy que hacía corresponder al citado prelado el inicio de la construcción de una nueva iglesia: "Tunc reverendus Episcopus Legionensis Manricus, eiusdem Sedis Ecclesiam fundavit opere magno, sed eam ad perfectionem non duxit» ${ }^{1}$. Dos siglos más tarde, Manuel Risco identificó las construcciones promovidas por Manrique con la actual catedral gótica, y el equívoco habría de perdurar hasta que en la presente centuria M. Gómez Moreno y E. Lambert demostraron una cronología más tardía para la iglesia

* El presente trabajo es el resultado de la revisión y puesta al día de una hipótesis ya desarrollada en la Tesis Doctoral titulada Investigaciones iconográficas sobre la escultura funeraria del siglo XII en Castilla y León, realizada bajo la dirección del Prof. Dr. D. Serafín Moralejo Alvarez y publicada en microficha por el Servicio de Publicaciones de la Universidad de Santiago de Compostela en 1993. Su revisión me ha permitido reafirmarme en la hipótesis de la existencia de un primitivo programa monumental en el capítulo leonés. Con posterioridad al envío de este artículo a la redacción de la revista en 1994, G. Boto Varela ha publicado "1200 en León. Esculturas de la antigua catedral románica", Boletín del Museo e Instituto "Camón Aznar», LIX-LX (1995), pp. 83-117; y La memoria perdida. La catedral de León (917-1255), León, 1995, en donde en las páginas 86-100 vuelve a aludir a las mismas piezas, defendiendo opiniones diferentes a las que aquí se presentan. Recientemente se ha hallado una inscripción en pésimo estado en una de las piezas -la que propongo como el Obispo Alvito- en la que se ha querido ver la firma de Matheus.

1 Cfr. Fr. A. de Lobera, Grandezas de la muy antigua e insigne ciudad e iglesia de Leon, Alcalá 1595, (ed. facsímil León, 1987), pp. 75 y 77. La cita del Tudense en Crónica de España por Lucas de Tuy, ed. J. Puyol, Madrid, 1926 , p. 441. 
leonesa ${ }^{2}$. En consecuencia se relegó a un segundo plano la cuestión del alcance de las obras en tiempo de Manrique, interpretando como exageración laudatoria las palabras del Tudense, quien antes de ocupar la sede gallega había sido canónigo de San Isidoro. La confrontación de algunos restos arqueológicos repartidos hoy entre el claustro y el Museo catedralicio con la documentación conservada permitirá devolver la razón, al menos en parte, al deán leonés del siglo xvi.

De 1186 data el único y pobre testimonio de la obra realizada en el claustro de la catedral leonesa durante el siglo XII ${ }^{3}$. La construcción de un nuevo recinto de piedra habría de sustituir a la primitiva construcción de materiales poco resistentes, levantada bajo los auspicios del obispo Pelayo, y terminado con anterioridad al $1073^{4}$. De su decoración escultórica se conservan únicamente algunas arcadas sobre parejas de columnas, aparecidas en 1915 en el transcurso de las obras de pavimentación del actual claustro; y dos capiteles entregos que Manuel Gómez Moreno reconoció en el Museo de San Marcos. La escultura de estos capiteles, de muy variado estilo, confirman la hipótesis de una construcción episódica que también se puede deducir a través de la información que proporciona la documentación conservada ${ }^{5}$.

Aunque el único testimonio documental de la obra data de 1186, un año antes se había, al menos, planeado el refectorio, pues el Libro de Obitos conservado en el Archivo de la catedral siúa en ese año la muerte del arcediano don Thomas "qui fecit refectorium» ${ }^{6}$. Más difícil resulta determinar si ya entonces se labró «la Maiestat» de la "porta del refertoriu» ante la cual ordenaría ser enterrado el canónigo Isidro Pérez en $1250^{7}$. Aunque por Majestad puede entenderse tanto una imagen de María como Sedes Sapientiae, como la imagen de Cristo entronizado, en este caso cabría aventurar la segunda posibilidad, pues entre los hallazgos realizados durante las obras de acondicionamiento de la sala capitular E. Fernández y M. Valdés acertaron a ver un tímpano con «los restos de un pantócrator», practicamente destruído ${ }^{8}$.

Bajo el episcopado de Manrique debió concebirse también la idea de dotar al claustro romá-

2 Cfr. M. Risco, Historia de León. Iglesia de León, y monasterios antiguos y modernos de la misma ciudad, Madrid, 1792, pp. 54-55; M. Gómez Moreno, Catálogo Monumental de la Provincia de León, Madrid, 1925, pp. 219-222 y E. Lambert, El arte gótico en España en los siglos XII y XIII, Madrid, 1985 (1ºd. París, 1933), pp. 228-232.

3 El arcediano de León D. Nicolás legaba en su testamento "opere Sante Marie unun moropitinun. Claustro Sancte Marie unun moropitinun (sic)». Cfr. J. M. Fernández Catón, Documentación de la Catedral de León, III, León, 1990, pp. 57 O-572.

$4 \mathrm{Al}$ igual que la iglesia ordenada construir por el mismo prelado debía de ser de materiales poco resistentes, ya que cuarenta años más tarde el obispo don Diego lamenta el estado deplorable en que se encontraba el templo y el resto de las construcciones anejas. Cfr. M. Risco, España Sagrada, XXXVI, Madrid, 1784, apéndice LIX; y J. M. Fernández Catón, Documentación de la Catedral de León, III, pp. 52-54.

5 De la documentación puede deducirse que desde 1133 debió empezar a plantearse la construcción del claustro, ya que el obispo D. Arias establece que todas las donaciones sean "ad officium refectorii et coquine» para sufragar los gastos comunes de la canónica. Cfr. Fernández Catón, Documentación, III, pp. 159-162. En tales términos realizan importantes donaciones la infanta doña Elvira en 1133 y 1136 y Alfonso VII y Doña Berenguela en 1135 y 1141 (Ibid., pp. 164-166, 179. 181, 171-174, 203-204). El documento del obispo D. Arias fue confirmado por su sucesor Juan Albertino, quien en su testamento de 1152 realiza una donación en tales términos (Ibid., 256-266). Desde el 1157 se suceden cuantiosas donaciones a la obra de Santa María, entre ellas algunas de los monarcas leoneses, y dado que no existe testimonio de actividad edilicia en la iglesia por esas fechas, cabe deducir que el distino de las mismas habría de ser el claustro. Cfr. Ibid., pp. 210-211, 304-305, 306-307, 312-314, 326-327, 381-384, 479-481; sobre los restos, cfr. M. Gómez Moreno Catálogo, pp. 219 y 310.

6 Cfr. Demetrio de los Ríos, La catedral de León, León, 1989, (ed. facsímil, Madrid, 1895) II, p. 164. Don Thomas el arcediano debía ser un personaje especialmente influyente por su estrecha relación con la familia real leonesa. En 1177 Fernando II en unión de su hijo Alfonso dona a la iglesia de Santa María de León y a don Thomas "carissimi et venerabili archidiacono", un molino con una presa en Torío, "pro bono servicio quod michi Thomas liberaliter exhibuit", cfr. Fernández Catón, Documentación, V, pp. 479-482.

7 Para los testimonios documentales sobre las capillas del claustro, y la portada del refectorio, cfr. J. M. Ruiz Asencio, Collección Documental del Archivo de la catedral de León, VIII (1230-1269), León, 1993, pp. 142-143, 170 y 171.

8 Cfr. E. Fernández y M. Valdés, "Recientes hallazgos artísticos en la catedral leonesa”, León Medieval.Doce Estudios, León, 1978 , pp. 235-241, espec. p. 238, citan entre los hallazgos encontrados los restos de un tímpano con un pantócrator con nimbo crucífero, pero señalan que ya entonces se encontraba prácticamente destruído. 
nico con una sala capitular magníficamente decorada. De la estructura original de dos pisos comunicados por una escalera, queda en pie el recinto superior en el que, a pesar de las alteraciones sufridas, puede reconocerse todavía parte del aparejo primitivo y algunos fragmentos de pinturas al fresco 9 . Apoyaba el edificio sobre la nueva muralla leonesa, una reconstrucción «ex lapidibus et calces de la antigua cerca de materiales poco resistentes, llevada a cabo alrededor del $12 \mathrm{OO}^{10}$. La obra del cabildo estaría concluída en 1224 , como se desprende del testimonio que proporcionan las Constituciones Sinodales promulgadas ese mismo año: «Ad haec statuimus, $u t$ non alibi quam in loco ad hoc facto et specialiter deputato Capitulum celebretun ${ }^{11}$.

En distintas obras realizadas posteriormente en las dependencias del claustro leonés han ido apareciendo sucesivamente diversos fragmentos escultóricos, que, como ha sugerido S. Moralejo, por su estilo, por su peculiar formato, y por la relación iconográfica establecida entre algunas imágenes en ellos representadas, sugieren la primitiva existencia de una importante decoración monumental en el recinto inferior de la sala capitular, y atestiguan la temprana llegada a León de escultores familiarizados con los repertorios formales del primer gótico francés ${ }^{12}$.

\section{La recuperación de las piezas: filiación estilística y disposición original}

En la sala de piedra del Museo Catedralicio y Diocesano de León se conserva un relieve con un Cristo entronizado señalando con su mano derecha un texto perdido del libro abierto que apoya en su rodilla (Fig. 1). Su anterior localización -anteriormente esta pieza estuvo empotrada, junto con otros dos relieves, bajo un arcosolio del siglo xvi en el muro sur del claustro-, y la presencia de un epitafio en su parte inferior - «IN HOC TUMULO JACET PETRUS LUPI PRESbIter ET CANONICUS HUJUS ECCLEsiae...QUI OBIIT ERA...»- invitaron a los distintos autores que se han ocupado de ella hasta la fecha a proponerle un destino primitivo como parte integrante de otro monumento funerario más antiguo localizado en el primitivo claustro de piedra ${ }^{13}$. Sin embargo la insólita disposición del epitafio, y el inadecuado formato de la pieza con respecto al amplio abanico de soluciones desplegadas en la escultura funeraria contemporánea, inclina a suponer que se reutilizó como complemento mural de un sepulcro un elemento integrante de otro tipo de programa, fe-

9 Sobre la sala capitular, cfr. E. Fernández y M. Valdés, «Recientes hallazgos», pp. 235-241. Ocupando más de la mitad del recinto inferior se construyó a principios del siglo xv la capilla de Santa Catalina, y a finales del mismo y comienzos del siguiente se realizaron importantes obras de acondicionamiento en el piso superior. Las alteraciones sufridas afectaron también al tramo que quedaba en pie del recinto inferior, y a la escalera de comunicación, levantándose en su lugar, la actual escalinata renacentista. Cfr. R. Rodríguez, "Actas capitulares de la catedral de León", Archivos leoneses, (1957), p. 183 y 317; y Waldo Merino, Arquitectura hispano-flamenca en León, León, 1974, p. 340 y 364.

10 Aunque el Tudense, que escribía bajo el patronazgo de la reina Berenguela, atribuyó a ésta la reconstrucción de la muralla leonesa "ex lapidibus et calce» hacia $12 \mathrm{OO}$ (Cfr. Crónica de España, ed. cit., p. 411), cabría reconocer en el pasaje de nuevo una exageración laudatoria. Cfr. E. Benito Ruano, «Las murallas y cercas de la ciudad de León durante la Edad Media", León Medieval. Doce Estudios, León, 1978, pp. 25-41, espec. pp. 30-31.

11 Cfr. M. Risco, España Sagrada, XXXV, p. 426.

12 Ya S. Moralejo en "La Fachada de la sala capitular de la Daurade de Toulouse. Datos iconográficos para su reconstrucción", Anuario de Estudios Medievales, 13 (1983), pp. 179-2O4, espec. p. 19O, n. 5 O había sugerido la posibilidad de la existencia de un programa decorativo para la sala capitular leonesa.

13 Para su instalación anterior, cfr. J. M. Quadrado, España. Sus Monumentos y Artes. Su Naturaleza y su Historia, Asturias y León, Barcelona, 1885, p. 47O; E. Serrano Fatigati, "Relieves del claustro de la catedral de León", Boletín de la Sociedad Española de Excursiones, X (19O2), no. 114-116, pp. 17O-175; M. Gómez Moreno, Catálogo, I, pp. 237-238; II, fig. 235; G. Weise, Spanische Plastik aus sieben Jahrhunderten, Reutlingen, 1925, I, p. 14, y M. Berrueta, La catedral de León, Madrid, 1951, p. 132. La variedad de formatos de los tres relieves que ocupaban el fondo del nicho lleva a pensar que el conjunto es fruto de una reinstalación de las piezas, procedentes de un primitivo destino común. Cfr. también A. Franco Mata, Escultura Gótica en León, León, 1976, pp. 419-42O, E. Fernández y M. Valdés, "Recientes hallazgos», p. 241; E. Gómez Moreno, La catedral de León, León, 1984, p. 35; M. Gómez Rascon, Museo Catedralicio-Diocesano de León, Madrid, 1983, p. 10, y F. Llamazares, Museos de León y Provincia, León, 1985, p. 94. 

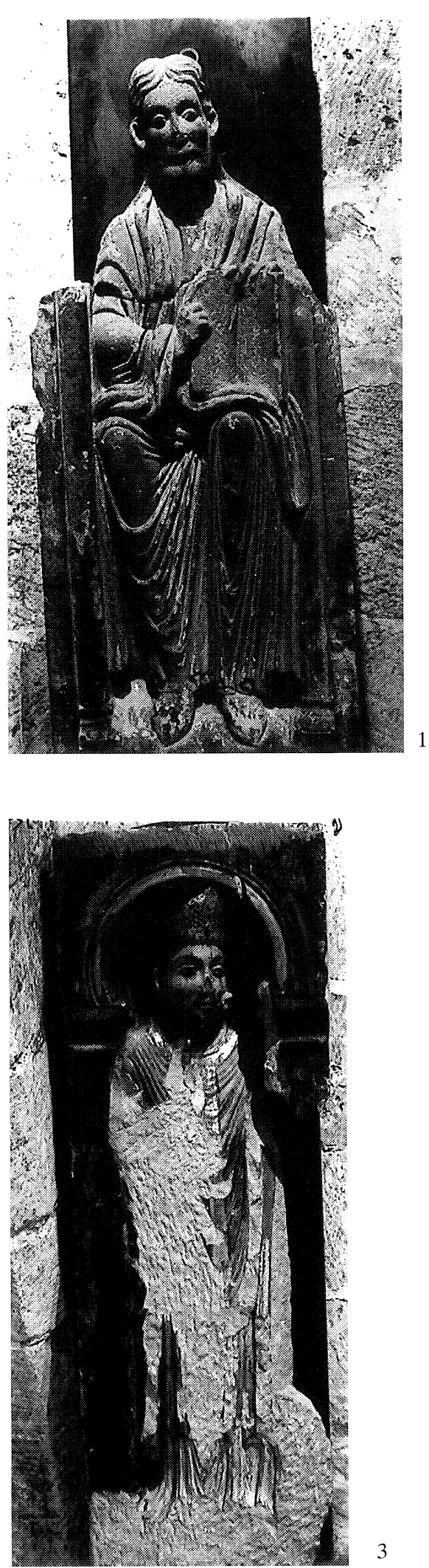
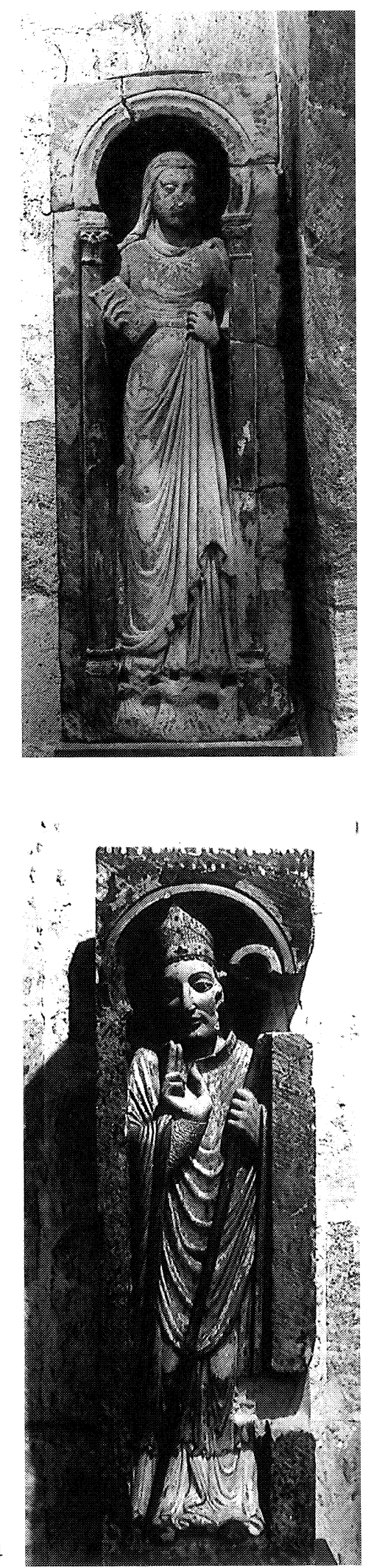

Fig. 1. El Salvador. Museo Catedralicio y Diocesano de León. (Foto: R. Yzquierdo).

Fig. 2. María Anunciada. Museo Catedralicio y Diocesano de León. (Foto: R. Yzquierdo).

Fig. 3. San Alvito (?). Museo Catedralicio y Diocesano de León. (Foto: R. Yzquierdo).

Fig. 4. San Froilán (?). Museo Catedralicio y Diocesano de León. (Foto: R. Yzquierdo). 
nómeno para el que se conocen precedentes y paralelos en la península y fuera de ella ${ }^{14}$. Al igual que Isidro Pérez habría de ordenar enterrarse ante la Majestad de la portada del refectorio, Pedro López pudo haber hecho lo propio con la de la fachada de la sala capitular.

La similitud de formato con otras piezas atribuibles al programa capitular sería otro argumento aducible en este sentido. En efecto, pese a su estado fragmentario, las basas y la parte inferior de las columnillas que enmarcan al Cristo entronizado permiten suponer la existencia de un arco que cobijase originariamente a la figura. La pieza presentaría, entonces, un formato idéntico al de otros tres relieves conservados en el mismo recinto: el de la mujer velada que acompañaba a aquél en su anterior localización en el claustro (Fig. 2), y otros dos con figuras de obispos vestidos de pontifical, aparecidos en 1976 en el transcurso de las obras de limpieza y restauración de la sala capitular (Figs. 3 y 4) ${ }^{15}$.

Hasta el momento se han evocado las figuras de la sala capitular de la Daurade de Toulouse, o incluso el arte silense, el mateíno o las figuras de la Cámara Santa ovetense, como paralelos estilísticos para el relieve del Cristo entronizado ${ }^{16}$. Sin embargo, a mi juicio, los referentes estilísticos habrán de buscarse en el arte champañés y del dominio real francés. La firme voluntad estatuaria que se manifiesta en la considerable proyección volumétrica de cabeza y rodillas se conjuga con una concepción de los plegados que denuncia la influencia de las artes del metal, y con el preciosismo caligráfico desplegado en la rítmica ondulación de la cabellera o en el remate ornamental de la barba. Estos rasgos definen un estilo cuyo origen habrá de encontrarse en la escultura del Norte de Francia de la década de 117O. Más que «presentir el arte de Senlis» como apuntaba M. Gómez Moreno, el relieve leonés lo refleja. El modo en que el manto de Cristo se recoge sobre la rodilla derecha deriva de una receta que W. Sauerlander señaló común a un fragmento de estatua- columna procedente del claustro de Notre-Dame-en-Vaux de Châlons-sur-Marne y a la jamba con el Moisés de Senlis ${ }^{17}$. La sólida construcción del rostro de fuertes mandíbulas y marcados arcos sopraciliares, recuerdan, en efecto, algunas estatuas-columna del programa claustral francés: un rey del antiguo testamento, hoy en el Museo del citado claustro y un Evangelista conservado en el Fine Arts Museum de Cleveland (Fig. 10) (Ohio). Ambas piezas fueron fechadas por L. Pressouyre

14 La hipótesis del destino original en la portada capitular no excluye su posterior reutilización funeraria. Para precedentes y paralelos para la reutilización de vanos de salas capitulares como complemento mural para sarcófagos tanto en la península como fuera de ella. Cfr. R. Sánchez, Investigaciones, pp. 23-27. La ausencia de la fecha del óbito en el epitafio implica que el monumento fue labrado en vida de su destinatario, y se sabe que este personaje aún vivía en 1193 (Cfr. A. Franco Mata, Escultura Gótica, p. 240), por lo tanto la reutilización debió llevarse a cabo en el última década del siglo xII o en la primera del XIII, apenas concluída la fachada del capítulo o incluso sin que ésta estuviera rematada.

15 Sobre la imagen femenina, cfr. nota 13, y para los relieves de obispos, cfr. E. Fernández y M. Valdés, «Recientes hallazgos", pp. 238-241.

16 Aunque los diversos autores que se han ocupado de la pieza coinciden en fecharla a fines del siglo XII y comienzos del XIII, divergen, en cambio, en lo que a la filiación estilística se refiere. G. Weise, Spanische Plastik, p. 14, lo pone en relación con la Daurade de Toulouse, y para M. Gómez Moreno, León, p. 237 esta escultura "presiente el arte de Senlis". E. GómezMoreno, La catedral de León, p. 35 propone un filiación compostelana, que ya descartó A. Franco, Escultura Gótica, p. 419. G. Boto tanto en "1200 en León", pp. 91-93, como en La memoria olvidada, p. 92 relaciona estilísticamente estas figuras con las estatuas de la Cámara Santa oventense, que a mi juicio se corresponden con un estadío más temprano, o al menos más primitivo en lo que a proyección de bulto e instalación en el espacio se refiere -compárense, por ejemplo la actitud de los pies en ambas series-. Para el grupo ovetense, cfr. E. Fernández González, «Estructura y simbolismo en la capilla palatina y otros lugares de peregrinación", Las peregrinaciones a Santiago de Compostela y San Salvador de Oviedo en la Edad Media, Oviedo, 1993, pp. 335-399. Boto supone que estas piezas pudieron haber pertenecido a una portada de la catedral románica, e identifica a la figura femenina como una "personalización de una Sibila" (sic), en razón de su ausencia de nimbo, defendiendo como suya la propuesta de la presencia de otra Sibila en el Pórtico de la Gloria compostelano, propuesta debida, en cambio, a S. Moralejo, quien la expuso en el Simposio Internacional "O Portico da Gloria e a Arte do seu Tempo». Cfr. R. SANCHEZ, "O Pórtico da Gloria e a Arte do seu Tempo'. Simposio Internazionale organizzato dalla Conselleria de Cultura de la Xunta de galicia, Santiago de Compostela, 3-8 ottobre 1988", Arte Medievale, II Serie, Anno IV, 1 (1990) 197-198.

17 Cfr. W. Sauerlander, "Twelth-century sculpture at Chalons-sur-Marne», Romanesque and Gothic Art. Acts of the twentieth International Congress of the History of Art, I, Princeton, 1963, pp. 19-129, espec. pp. 123-124, lams. XL, 16 y 17. 

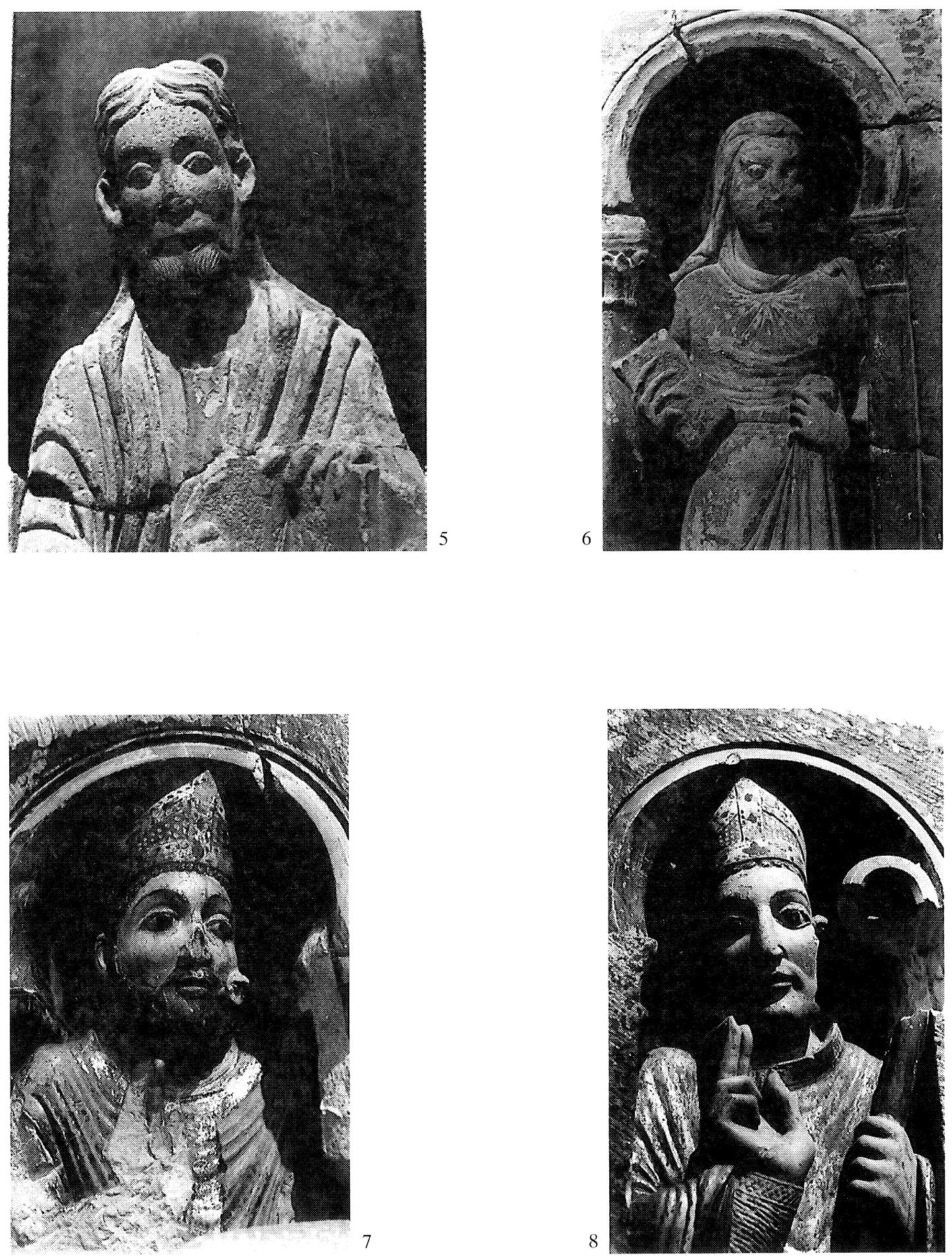

Fig. 5. El Salvador. Museo Catedralicio y Diocesano de León. Detalle. (Foto: R. Yzquierdo).

Fig. 6. María Anunciada. Museo Catedralicio y Diocesano de León. Detalle. (Foto: R. Yzquierdo)

Fig. 7. San Alvito (?). Museo Catedralicio y Diocesano de León. Detalle. (Foto: R. Yzquierdo).

Fig. 8. San Froilán (?). Museo Catedralicio y Diocesano de León. Detalle. (Foto: R. Yzquierdo). 
con anterioridad al 1184, y atribuídas al que ha denominado "maestro de Daniel», autor de la estatua del profeta que le ha dado nombre (Fig. 9) y que, al igual que el Cristo leonés, presenta unas largas manos con dedos huesudos, excepcionalmente abiertos, que más parecen garras de animal que dedos de persona (compárense Figs. 1 y 9) ${ }^{18}$. El diseño de los pliegues, una inorgánica superposición de protuberancias de aristas duras que se superponen a volúmenes redondeados (obsérvense especialmente los hombros, el codo derecho y el remate inferior alrededor de los pies) parecen evocar las fórmulas utilizadas en el claustro francés citado o en algunas estatuas-columna hoy en el Musée Municipal de Laon, que originariamente decoraron la fachada occidental de la catedral, fechada hacia 1200 (Figs. 1, 11 y 12) ${ }^{19}$.

En los relieves de prelados y en la imagen femenina están presentes algunos de estos rasgos estilísticos -los obispos presentan cabezas con una sólida arquitectura ósea y la imagen femenina los característicos dedos ganchudos (Figs. 2, 3, 4, 6, 7, 8, 9 y 10)-, sin embargo éstos se conjugan con un modelado más suave con transiciones menos bruscas, que denuncian la presencia de otros obradores, representantes de otras corrientes del primer gótico, activos en la misma empresa. La figura femenina está emparentada con un relieve de formato rectangular con un «caballero victorioso" despidiéndose de su dama, hoy empotrado en el muro norte del vestíbulo del claustro, que debió formar parte también del programa claustral (Figs. 2, 6, 13, 14, 15) ${ }^{20}$. Tanto la rotundidad del bulto como el estilo de los ropajes, con transiciones de volumen más suaves, en ambos ejemplos lleva a pensar en el conocimiento de formas de Laon, como las arquivoltas del portal izquierdo u otros profetas de la serie estatuaria (Figs. 2, 12 y 13) ${ }^{21}$. Aunque no pretendo defender que Laon constituya la fuente directa para las piezas leonesas, en términos generales, ambos conjuntos reflejan las mismas raíces artísticas.

El formato de las piezas leonesas proporciona seguros indicios sobre la función que hubieron de desempeñar en la sala capitular. Se trata de figuras enmarcadas por una arcada sostenida por columnas, como es habitual en otros programas monumentales de capítulos del sur de Francia. Cabe evocar como precedente la Virgen entronizada de la sala capitular de la Daurade de Toulouse, con la que comparten la morfología de la decoración escultórica del marco ${ }^{22}$. Sin embargo, la altura de las piezas leonesas excede, por lo menos, en veinte centrímetros a aquélla, siendo, en cambio, más estrechas; y además se vacía el vano del arco, cuya forma de herradura cabe explicar en razón de exigencias iconográficas, además, quizá, de un retorno deliberado a la antigua tradición mozárabe o una evocación a prestigiosos modelos locales ${ }^{23}$. En efecto, la ausencia de nimbo en todas las figuras, incluso en la de Cristo resulta, en principio sorprendente. No lo sería tanto suponiendo a estas piezas un destino primitivo como celosías para el cabildo, solución sin precedentes conocidos,

18 Para la estatua columna en el Fine Arts Museum de Cleveland (Ohio), cfr. W. Sauerlander, La Sculpture Gothique en France, 1140-127O, París, 1975, pp. 92-93, lam. 52; y para la definición del estilo del maestro de Daniel, cfr. S. y L. Pressouyre, Le cloitre de Notre-Dame-en-Vaux, París, s. d., pp. 4, fig. 8 y 9.

19 Cfr. W. Sauerlander, La sculpture gothique, lam 72.

20 Sobre este último relieve, cfr. M. Gómez Moreno, León, I, p. 282, quien lo adscribe a un taller compostelano derivado del de Mateo. Cfr. también M. Ruiz Maldonado, «El Caballero Victorioso en la escultura románica española. Algunas consideraciones y nuevos ejemplos", Boletín de Seminario de Estudios de Arte y Arqueología, (1979), pp. 271 y ss., espec. p. 277; Eadem, El caballero en la escultura románica de Castilla y León, Salamanca, 1986, p. 1O2, fig. 62.

21 Cfr. W. Sauerlander, La sculpture gothique, pp. 105-108, figs. 50-52, lám. 72.

22 Para la Virgen de la Daurade, cfr. S. Moralejo, "La fachada", espec. pp. 18O-182, fig. 1. En este artículo resume las aportaciones de L. Seidel, K. Horste y M. Durliat sobre el controvertido programa de esta sala capitular.

23 Las dimensiones de las piezas leonesas oscilan alrededor de los 1.58/O.45 metros. Cfr. E. Fernández y M. Valdés, "Recientes hallazgos», p. 238. Las piezas de La Daurade, de San Esteban de Toulouse, la única estatua-columna conservada del claustro de Saint-Denis y la "Mare de Deu» de Solsona, cuyo claustro presentaba un programa monumental vinculado a los tolosanos, medían, en cambio, 1.17 metros de alto. Sobre ello, cfr. S. Moralejo, «De Sant Esteve de Tolosa a la Daurade. Notes sobre l'escultura del claustre romànic de Santa María de Solsona" Quadern d'estudis medievals, n. 23-24 (1988), pp. 104-109, espec. p. 176, n. 19. 


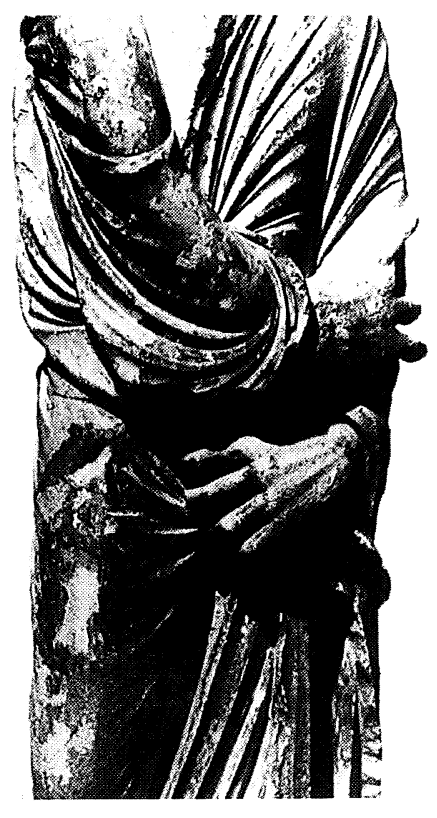

9

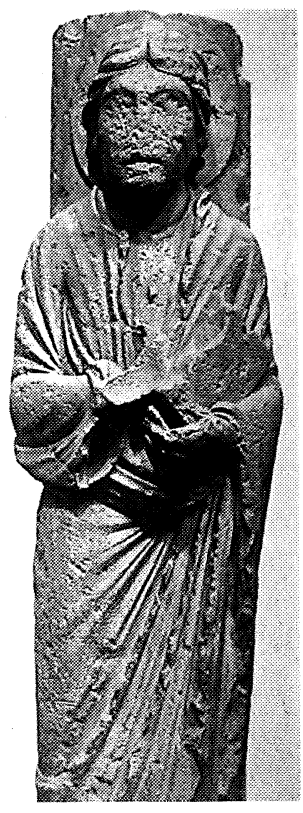

10

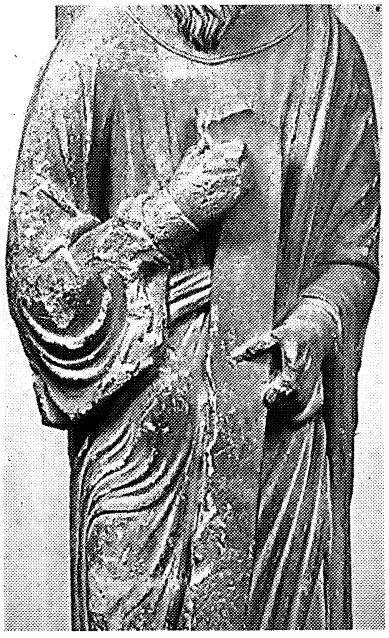

11

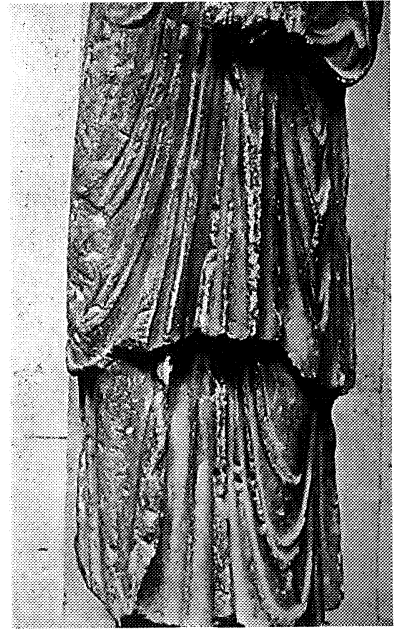

12

Fig. 9. Estatua-columna del claustro de Notre-Dame-en-Vaux de Châlons-sur-Marne. (Foto tomada de L. Pressouyre, Le cloître de Notre-Dame-en-Vaux, París, s. d.).

Fig. 10. Estatua-columna procedente del claustro de Notre-Dame -en-Vaux de Châlons-sur-Marne. Cleveland Museum of Art (Ohio). (Foto tomada de W. Sauerlander, La Sculpture gothique en France, fig. 52).

Fig. 11. Profeta. Musée Municipal de Laon. Procedente de la fachada occidental de la catedral. Detalle. (Foto tomada de W. Sauerlander, La Sculpture gothique en France, fig. 72).

Fig. 12. Profeta. Musée Municipal de Laon. Procedente de la fachada occidental de la catedral. Detalle. (Foto tomada de W. Sauerlander, La Sculpture gothique en France, fig. 72). 
pero que no desentona con presupuestos característicos de la estética del primera gótico, como son la valoración del vano arquitectónico como soporte para un elemento iconográfico, y la experimentación con efectos causados por la luz natural para fines estéticos. Podría incluso decirse que se trata de figuras-mainel de ventana que han alcanzado un extraordinario desarrollo.

La posterior fortuna de la solución de estatuas alojadas en arcadas en otros programas monumentales de salas capitulares castellanas viene a confirmar esta hipótesis. Me refiero a dos ejemplares lamentablemente desaparecidos, pero conocidos a través de testimonios gráficos: la de la "capilla» de la bailía templaria de Ceinos de Campos (Valladolid) y la del monasterio premonstratense de Santa María de Benevívere (Palencia) (Figs. 16 y 21) ${ }^{24}$. Por último, cabría añadir que una serie estatuaria de claustro con un programa parecido se labró en el segundo cuarto del siglo XIII en el vecino monasterio benedictino de Sahagún, como ha puesto de manifiesto R. Steven Janke. Las columnas "con vultos labrados» que Ambrosio de Morales describió se encuentran repartidas hoy entre el Fogg Art Museum de Cambridge (Mass.) -un San Miguel y un San Pablo- y el Museo de San Marcos de León - un Cristo en majestad y una Virgen con el Niño- ${ }^{25}$.

El singular formato de la celosía figurada debió surgir en un ámbito familiarizado con las estatuas-columna. De hecho, otra diferencia notable con respecto al relieve de la Daurade es la instalación mucho más audaz de las figuras en el marco. A excepción del Cristo sedente, de actitud más rígida, como corresponde a su rango, las otras tres estatuas se mueven con relativa libertad bajo las arcadas. La mujer recoge el manto con su izquierda en un gesto que puede interpretarse como un amago de movimiento (Fig. 2). Uno de los obispos se gira de tal manera en ese sentido, que el hombro correspondiente sobresale fuera del plano que aloja la arcada que lo alberga (Fig. 3). Lo mismo sucede con la mitra del otro prelado, al inclinar éste su cabeza, mientras bendice (Fig. 4). Por sus actitudes y sus conquistas espaciales, estos relieves remiten a un estadío ya evolucionado en el desarrollo de la estatua-columna, que se ajusta perfectamente al origen supuesto para ellos por medio del análisis estilístico.

Otros dos relieves conservados en la misma sala del Museo Catedralicio y Diocesano, que representan un San Pedro y un San Pablo pudieron haber pertenecido también a este conjunto

\footnotetext{
${ }^{24}$ Sobre el conjunto de Ceinos de Campos, cfr. V. García Escobar, «La iglesia de los templarios en Ceinos», Semanario Pintoresco Español (1853), pp. 153-155; J. M. Quadrado, España. Sus Monumentos y Artes. Su Naturaleza e Historia. Valladolid, Palencia y Zamora, Barcelona, 1884, pp. 310-321; C. Nieto, «Descripción de la iglesia que con la advocación de Nuestra Señora del Templo poseyeron los caballeros templarios en la villa de Ceinos de Campos", Boletín de la Real Academia de la Historia, LXXVI (1920), pp. 268-274; A. Gaya Nuño, La Arquitectura española en sus monumentos desaparecidos, Madrid, 1961, pp. 141-144; J. Castan Lanaspa, "Aportaciones al estudio de la Orden del Temple en Valladolid", Boletín del Seminario de estudios de Arte y Arqueología, XLVIII (1982), pp. 199-200; idem, Arquitectura templaria castellano-leonesa, Valladolid, 1983, pp. 80-83. Los restos de la galería con decoración monumental se encuentran hoy en el Museo Arqueológico de Valladolid. Para Benevívere, Villamil y Escosura, España Artística y monumental, París, 1842, I, 4; J. Quadrado, Valladolid, Palencia y Zamora, p. 494; A. Gaya Nuño, Monumentos desaparecidos, pp. 144-146 y M. Carrión Gutiérrez, Carrión de los Condes, col. Apuntes Palentinos, 4, VI, Palencia, 1983, p. 29.

25 El testimonio de Morales, en Viaje de Ambrosio de Morales por orden del rey D. Phelipe II a los reynos de Leon, y Galicia, y principado de Asturias, ed. H. Flórez, Madrid, 1765, 39. Sobre las estatuas columnas del claustro, cfr. R. Steven Janke, "Two Statue Columns, Saint Paul and Saint Michael", Gothic Sculpture in America. The New England Museums, ed. D. Gillerman, Nueva York y Londres, 1989, pp. 176-177, con figs. Este autor defendió que se trataba de piezas de claustro frente a la opinión tradicional que las suponía tenantes de altar como las de San Pelayo de Antealtares. Para el paralelo portugués señalado por R. Steven Janke, cfr. T. Espanga, Inventário artístico de Portugal: Concelho de Evora, VII, Lisboa, 1966, 37-38, y figs. CXXXVI-CXXXVII. Para las piezas en el Museo de San Marcos en León, cfr. F. Llamazares, Museos de León y su provincia, León, 1985, p. 51, con fig. A ellas había ya hecho referencia, relacionandolas con el gótico clásico de la fachada occidental de la catedral de Amiens F. B. Deknatel, «Sculptured Columns from Sahagún and the Amiens Style in Spain", Medieval Studies in Memory of A. Kingsley Porter, I, Cambridge (Mass.), 1939, 301-10, esp. fig. 2.
} 

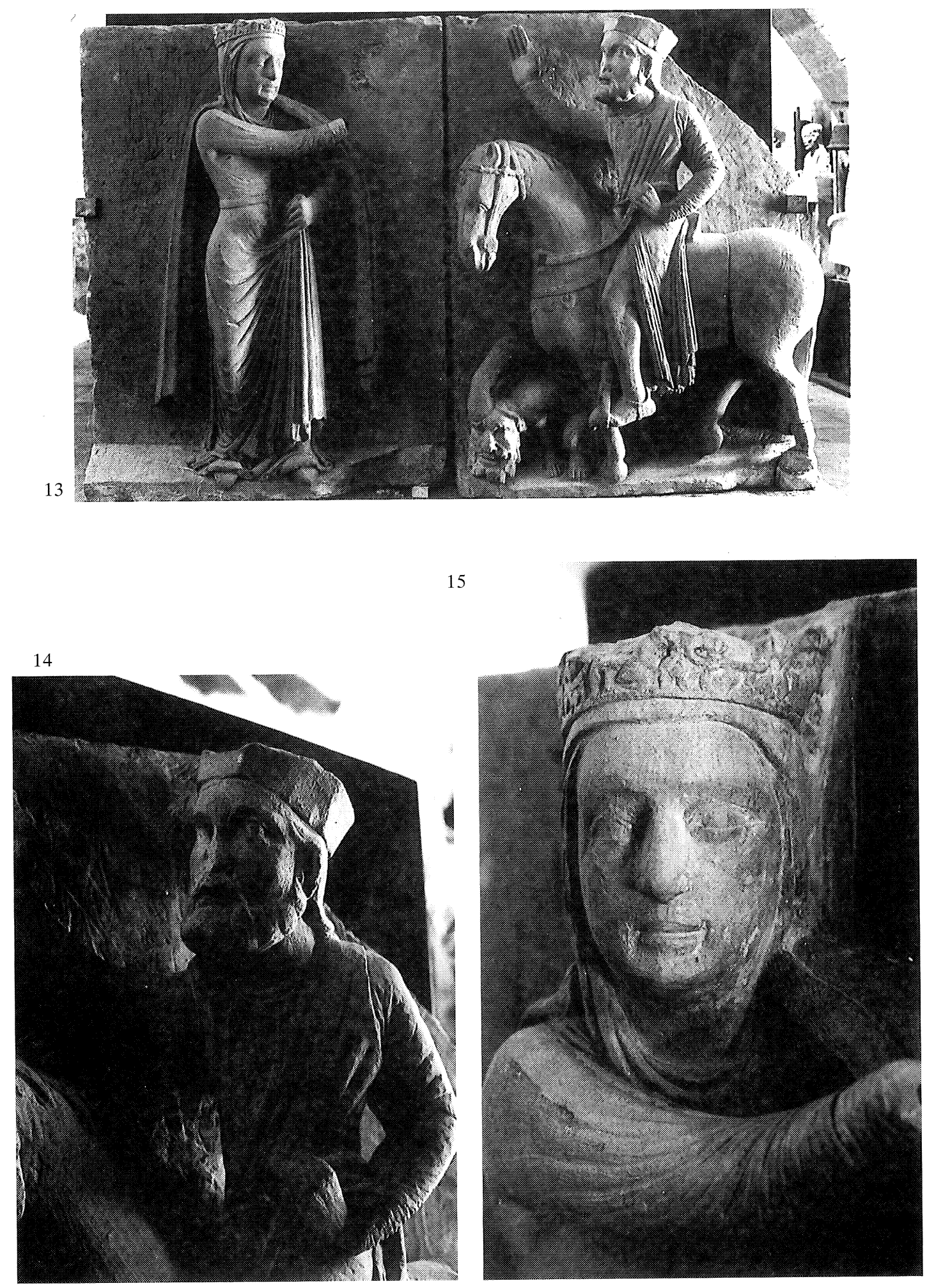

Fig. 13 "Caballero victorioso». Museo Catedralicio y Diocesano de León. (Foto: R. Yzquierdo)

Fig. 14 y 15. "Caballero victorioso». Museo Catedralicio y Diocesano de León. Detalle. (Foto: R. Yzquierdo). 
monumental (Figs. 18 y 19) ${ }^{26}$. Aunque muy distintos entre sí, ambos parecen pobres interpretaciones por parte de artistas locales de las novedosas fórmulas escultóricas propuestas por los talleres galos y cabe adjudicarles, en consecuencia, una cronología un poco posterior a la de las piezas labradas por aquéllos. El San Pablo es obra de un artífice que convierte lo que pudo haber sido un rico plegado en un diseño sinuoso completamente desvinculado de la anatomía de la figura, y el recuerdo de un «marmousset» de estatua-columna parece entreverse en los animales colocados a sus pies. Al San Pedro, por su tosquedad, cabría incluso imaginarle una cronología anterior, pero el primitivismo aparente es debido a la falta de oficio del escultor, que convierte en torpes líneas paralelas los plegados trasluciendo las formas del cuerpo que pretende imitar. En su incapacidad para comprender los avances espaciales de la escultura que le sirvió de modelo coloca la figura de un relieve casi plano apoyada en unos rotundos pies sobre una peana muy sobresaliente.

Ambas piezas presentan un formato más propio del románico que del gótico, pero como posibles miembros del programa monumental del capítulo parece más adecuado suponerles un destino en la cara interna de las jambas, como existieron, por ejemplo, en la sala capitular de Saint Caprais de Agen ${ }^{27}$, que imaginarlos como enjutas, tal como aparecían ambos apóstoles en la Portada del Perdón de la iglesia de S. Isidoro, ajustándose a una tradición anterior de estructura de portada típica de las portadas hispano-languedocianas.

\section{El programa iconográfico: la exaltación de la sede}

El limitado número de piezas conservadas no permite proponer una hipótesis reconstructiva detallada para la fachada de la primitiva sala capitular leonesa. Con todo, en la iconografía de los fragmentos rescatados puede reconocerse una intención similar a la de otros programas claustrales: la exaltación de la propia sede y de sus santos prelados se conjuga con la identificación mimética de la vita apostolica con la vita communis de los canónigos.

La actitud, indumentaria y atributos de la figura femenina - velada, con un libro en la mano, recogiendo el manto con la izquierda- son propios de una María Anunciada (Fig. 2). S. Moralejo ha señalado dos paralelos coetáneos para esta imagen: en un relieve empotrado hoy en el cuerpo superior de la fachada de Platerías de la catedral compostelana, y en un capitel de la Cámara Santa de Oviedo la Virgen de la Anunciación presenta una actitud semejante. A pesar de la ausencia de Gabriel, es posible que en León la escena se representase completa originariamente, como era, por lo demás, habitual por estas fechas en los programas monumentales de claustro ${ }^{28}$.

Las imágenes de María y el Salvador podrían, quizá, evocar las advocaciones principales de la cabecera de la catedral románica, todavía en uso cuando se ideó el programa de la sala capi-

26 Sobre los mismos, cfr. nota 13.

27 Sobre la sala capitular de Saint Caprais de Agen, cfr. S. Moralejo, "La fachada», p. 188; L. Seidel, "The Facade of the Chapterhouse al La Daurade in Toulouse», The Art Bulletin, LV (1973), pp. 328-333, fig. 2. G. Boto Varela, en La memoria olvidada, p. 92 pone en relación el estilo del relieve del San Pedro del claustro ovetense con el Cristo en Majestad leonés. Creo, en cambio, que es el el ámbito iconográfico en donde cabe señalar paralelos entre Oviedo y León. De hecho el San Pedro parece tomar el relevo de la serie relivaria románica. Sobre la misma, S. Moralejo, "Ars sacra' et sculpture romane monumentale: le trésor et le chantier de Compostella", Cahiers de Saint-Michel-de-Cuxá (1979) 10, pp. 29-58.

28 La pieza compostelana fue empotrada en este siglo en su actual localización, y enriquecida con un baldaquino. A su izquierda se colocó un Gabriel del siglo xv. Cfr. S. Moralejo, «Esculturas compostelanas del último cuarto del siglo XII", Cuadernos de Estudios Gallegos, XVIII (1973), pp. 295-310, espec. p. 305. La Anunciación aparece en el claustro de Santa María de Solsona, y en dos relieves de la cara interna de la entrada de la sala capitular de Saint-Caprais d'Agen. Para el caso de Solsona, cfr. S. Moralejo, «De Sant Esteve», pp. 107-108, figs. 3, 4 y para el caso de Agen, cfr. supra, nota 20. 
tular ${ }^{29}$, como estrechamente vinculados a la historia de la sede leonesa estarían también los dos santos prelados figurados en los otros dos relieves de idéntico formato (Figs. 3 y 4). Su santidad parece incuestionable ya que estaría sugerida por el nimbo de luz natural que su destino como celosías les confería. De hecho el modelo en el que parece haberse inspirado el escultor para labrar estas imágenes habrá de encontrarse en la miniatura que representa a San Isidoro en el volúmen de las obras de Santo Martino de León (Fig. 20) ${ }^{30}$. La diferente caracterización de los dos prelados facilitará su identificación. Uno de ellos es joven -con cabello y barba negra-, y en su indumentaria litúrgica el escultor siguió más de cerca el modelo: mitras y casullas son idénticas en ambos casos, azules, y adornadas con anchas bandas de oro (Figs. 3 y 20). El otro, en cambio, es un anciano con cabello y larga barba completamente canos, y en su actitud e indumentaria introduce variaciones con respecto al prototipo: sujeta el báculo, aferrándolo con su izquierda por la parte superior, y su atuendo presenta una mayor riqueza: la mitra es dorada, adornada de pedrería, y la casulla roja aparece salpicada de adornos dorados (Fig. 4).

Dos santos prelados leoneses parecen ajustarse especialmente a estas caracterizaciones: el longevo, y anterior en el tiempo Froilán, y Alvito cuya prometedora prelatura se vio frustrada por una muerte prematura. La Vita Sancti Froilani Episcopi narra como el santo, que rigió la diócesis a comienzos del siglo x, se trasladó a ella por requerimiento del pueblo leonés, desde el cenobio de Moreruela, cuya construcción había promovido ${ }^{31}$. En la nueva catedral gótica se le habría de dedicar toda una portada esculpida, y la estatua del parteluz que lo efigia viene a confirmar la identificación propuesta para el relieve de la sala capitular (Fig. 17). Respondiendo a la información que éste proporcionaba sobre el aspecto del santo, la estatua de la portada presenta su frente surcada de arrugas, como indicio de avanzada edad ${ }^{32}$.

El joven podría representar a Alvito, quien tras haber milagrosamente rescatado los restos del glorioso Isidoro en Sevilla, murió camino de León, cediéndole así el protagonismo del traslado al rey Fernando I, y las reliquias venerables a la iglesia de San Juan Bautista ${ }^{33}$.

Otra razón que abogaría por estas identificaciones sería que las reliquias de ambos obispos

29 Los ábsides estaban dedicados a Santa María, el Salvador y San Juan Bautista. Así lo especifica el obispo Pelayo en el acta de consagración de la iglesia en 1073. Cfr. M. Risco, España Sagrada, XXXVI, p. LIX. Al lamentable estado en que se encuentra y a su nueva dotación por él realizada se refiere el obispo don Diego en 1116. Cfr. Fernández Catón, Colección Documental, V, pp. 52-54.

30 Para esta miniatura cfr. E. Fernández González, "Las miniaturas de los códices martinianos", Santo Martino de León, Ponencias del I Congreso Internacional sobre Santo Martino en el VIII Centenario de su obra literaria 1185-1985, León, 1987, pp. 513-546, espec. pp. 524-525, lam. I. Para una ilustración en color de la misma, cfr. A. Viñayo, La Colegiata de San Isidoro de León, fig. 31.

31 En el archivo catedralicio se conserva la Vita Sancti Froilani Episcopi, escrita por el diácono Juan, intercalada en el fol. 101 de una Biblia Gótica, códice $n^{\circ} 6$ del Archivo de la catedral de León. Cfr. C. Gil Atrio, Santos gallegos, Orense, 1968, pp. 11-22 y A. Franco Mata, Escultura Gótica, pp. 692-631, en donde se fecha su muerte en el año 875. Sin embargo M. Risco, Iglesia de León, p. 18, y A. Ubieto Arteta, en Listas Episcopales Medievales, 2 vols., Zaragoza, 1989, I, p. 191 sitúan su pontificado entre el 900 y el 905 . El desconocimiento de la fecha de la muerte en un autor supuestamente contemporáneo, el hecho de que el texto se halle interpolado en tres columnas que habían quedado sin escribir entre los Libros de Job y Tobías, y la diferencia observable entre la letra utilizada en la Biblia y la del texto hagiográfico, inclinan a pensar que se trata de una interpolación posterior. Una segunda redacción de la misma se encuentra en un Breviario gótico del archivo de la misma catedral. Cfr. A. Risco, España Sagrada, XXXIV, pp. 159-203. El formato elegido en la portada capitular para la representación el santo, como celosía, parece especialmente adecuado para las tópicas metáforas con las que al él se refiere el hagiógrafo: «lucerna super Kandelabro imposita, claritate lucis aternae iluminavit», "inluminavit eos lumine veron.

32 Para la estatua del parteluz, cfr. A. Franco Mata, Escultura Gótica, pp. 228-229, fig. XCVIII. La ausencia de barba, en este caso, respondería al afán de representar al santo ajustándose a las normas dictadas y reiteradas en las Constituciones Sinodales de 1240 y 1267 , en las que, efectivamente, se prohibía a los prelados su uso. Para las Constituciones Sinodales, cfr. A. Risco, España Sagrada, XXVI, apéndices CLVII y CLVIII.

33 El Silense describe la expedición pero no deja clara la causa de la muerte de Alvito. Cfr. Historia Silense, ed. Santos Coco, Madrid, 1931, pp. 82-85. Para otras versiones del hecho, cfr. infra. 

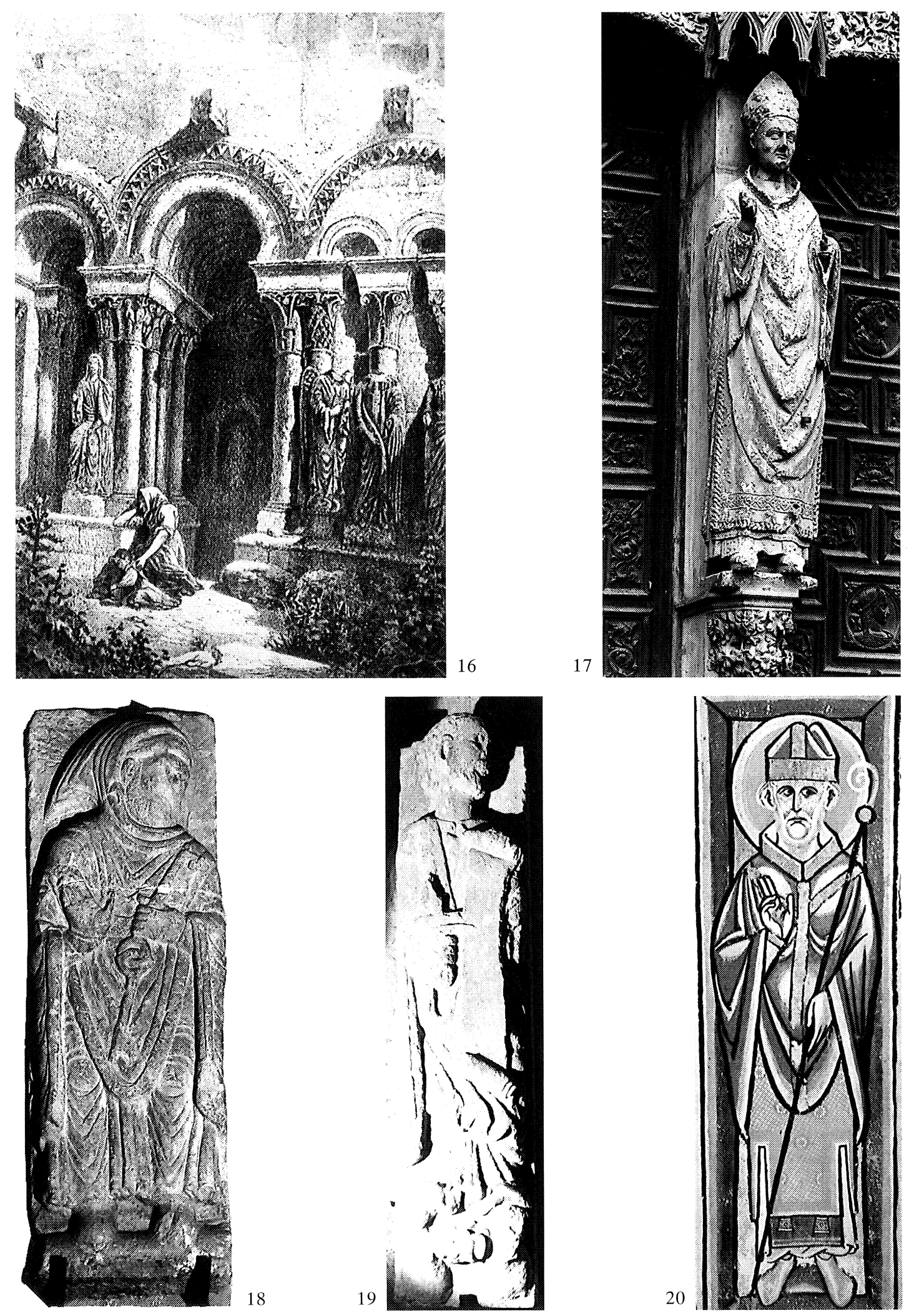

Fig. 16. Portada de la «capilla» de la bailía templaria de Ceinos de Campos (Valladolid).

Fig. 17. San Froilán. Parteluz de la portada sur de la catedral de León. (Foto: Archivo Mas).

Fig. 18. San Pedro. Museo Catedralicio y Diocesano de León. (Foto: E. Vidal).

Fig. 19. San Pablo. Museo Catedralicio y Diocesano de León. (Foto: E. Vidal).

Fig. 20. San Isidoro. Códice con las obras de Santo Martino. Archivo de san Isidoro de León. (Foto tomada de A. Viñayo, La colegiata de San Isidoro de León). 
santos se custodiaran en la catedral leonesa. El Silense refiere que, en 1063, Alvito fue enterrado con todos los honores en la catedral ${ }^{34}$. Posteriormente se mudó el santo cuerpo a un nuevo sarcófago, cuyos restos pueden verse todavía arrimados al muro norte del crucero de la actual catedral, con el siguiente epitafio: "ALVITuS PReSVL TVMvLATVS IN ISTO...VIT HVIC CRISTvs POnTIFICALE DECVS/ ..EX PerICOLE CELESTIS REX ....PAX ET REQUIEM...DA TIBI PERPETVE/ ERA MiLessima C ET QUOTo II NONas» ${ }^{35}$. Atendiendo a los caracteres del epitafio -letra pregótica tardía- y a la disposición de la inscripción en tres registros enmarcados por molduras a lo largo de la cubierta, cabría fechar el nuevo sepulcro entre finales del siglo XII y el primer tecio del XIII, es decir, cabría suponer la renovación del sepulcro coetánea a la empresa capitular.

Por estas fechas hubo también de rescatar León no sólo la memoria, sino también las reliquias del otro santo prelado. Los restos de Froilán, según las diferentes noticias que proporcionan las fuentes medievales, hubieron de perpetuar las ansias viajeras que habían caracterizado al santo en vida. Tras haber sido enterrado en su sede en un «monumento pretioso», sus restos fueron llevados a Moreruela para protegerlos de la furia de Alamanzor ${ }^{36}$. Lucas de Tuy en su De Miraculis Sancti Isidori da cuenta del milagroso traslado de la mitad del cadáver llevado a cabo en tiempos de Manrique de Lara, desde el monasterio de Moreruela, de modo que el santo prelado hubo de recorrer post mortem su propio cursus honorum que habría de culminar en la sede leonesa ${ }^{37}$. El episodio habría de ser posteriormente representado en el dintel de la portada sur de la catedral (Fig. 23).

La presencia de los dos santos prelados en el programa de la sala capitular, la labra de un nuevo sepulcro para Alvito, y el rescate de las reliquias de Froilán habrían de forma parte del complejo programa desarrollado por Manrique con objeto de prestigiar su sede, y si hoy se acoge con reservas la realidad histórica del "opere magno» que había caracterizado a la iglesia leonesa que había comenzado a construir, no cabría, en cambio, dudar de su interpretación alegórica, como metáfora de los variados esfuerzos del prelado por proporcinar a su iglesia un protagonismo en la capital del reino leonés, que hasta entonces había monopolizado San Isidoro.

34 La noticia del Silense en Historia Silense, ed. cit., p. 85: "Alvitus autem venerandus antistes in ecclesia Beate Marie cui prefuerat, Deo annuente habet sepulchrums.

35 M. Risco, Iglesia de León, p. 69, defiende que el cuerpo se mudó a en 1164 a una caja de madera en la que aparecían los siguientes versos: "Hac Patris Alviti Legionis praesulis almi/ condidit in theca Fernandus pignora sacra/ Aerae tunc anni duo praeter mille ducenti/ O sacer Alvite, memor esto gentis avitae/ da levitae Fernandus gaudia vitae». Dado que en 1527 se colocaron las reliquias en unos lugares altos del altar mayor (cfr. IBIDEM, p. 69) quizá a esta nueva caja correspondan los versos copiados por Risco, ya que en ellos aparece errada la fecha de la muerte - con un siglo de diferencia-, fruto de una equivocada lectura del epitafio original.

36 Para el monumento pretioso que en la Vita Sancti Froilani Episcopi se decía había albergado sus restos en la catedral, cfr. A. Franco Mata, Escultura Gótica, p. 289. Las reliquias se conservan hoy en la capilla mayor, en un arca de plata labrada a principios del siglo xvi, cfr. E. Gómez Moreno, La catedral, p. 54, fig. 48. En la sala de piedra de la catedral de León se conservan restos de un sarcófago estrigilado. Como mera hipótesis cabría preguntarse si no podría haber correspondido a un sarcófago romano reutilizado para albergar los restos de Froilán. La singularidad del epíteto "pretioso" recuerda a otras referencias a sarcófagos antiguos reutilizados en el siglo x, percibidos por los contemporáneos como piezas singulares y excepcionales. Cfr. al respecto S. Moralejo, «La reutilización e influencia de sarcófagos antiguos en la España Medieval", Colloqui sul reimpiego dei sarcofagi romani nel Medioevo, (Pisa 5-12 september 1982), Marburg, 1984, pp. 187-203. Cabría señalar también que únicamente las crónicas leonesas -el Silense y el Tudense-glosan la milagrosa muerte de san Alvito, y sitúan las reliquias de Froilán en León. Rodrigo Jiménez de Rada, habría de ser fiel a la versión de Pelayo de Oviedo en ambos asuntos. De Alvito se limitan a decir que ayudó a Fernando I a trasladar el cuerpo de Isidoro; y sitúan los restos de Froilán "infra Pyrenaeos montes,...super altare Sancti Joannis Baptiste». Cfr. Crónicas de los Reinos de Asturias y León, ed. Casariego, León, 1985, p. 175 y R. Jiménez de Rada, Historia de los hechos de España, ed. J. Fernández Valverde, Madrid, 1989, p. 206.

37 La noticia del Tudense en M. Risco, España Sagrada, XXXIV, p. 197: «En aquel mismo tiempo, esto es siendo obispo legionense D. Manrique, acaeció una cosa maravillosa, que trayendo del Monasterio, como a Santo tan glorioso convenía, en todo el camino por donde trahian aquellos huesos sacratissimos, et por alli al derredor llovia miel en tanta abundancia, que de los arboles, et de los cabellos de los hombres, et de los animales corrían arroyos de miel». 

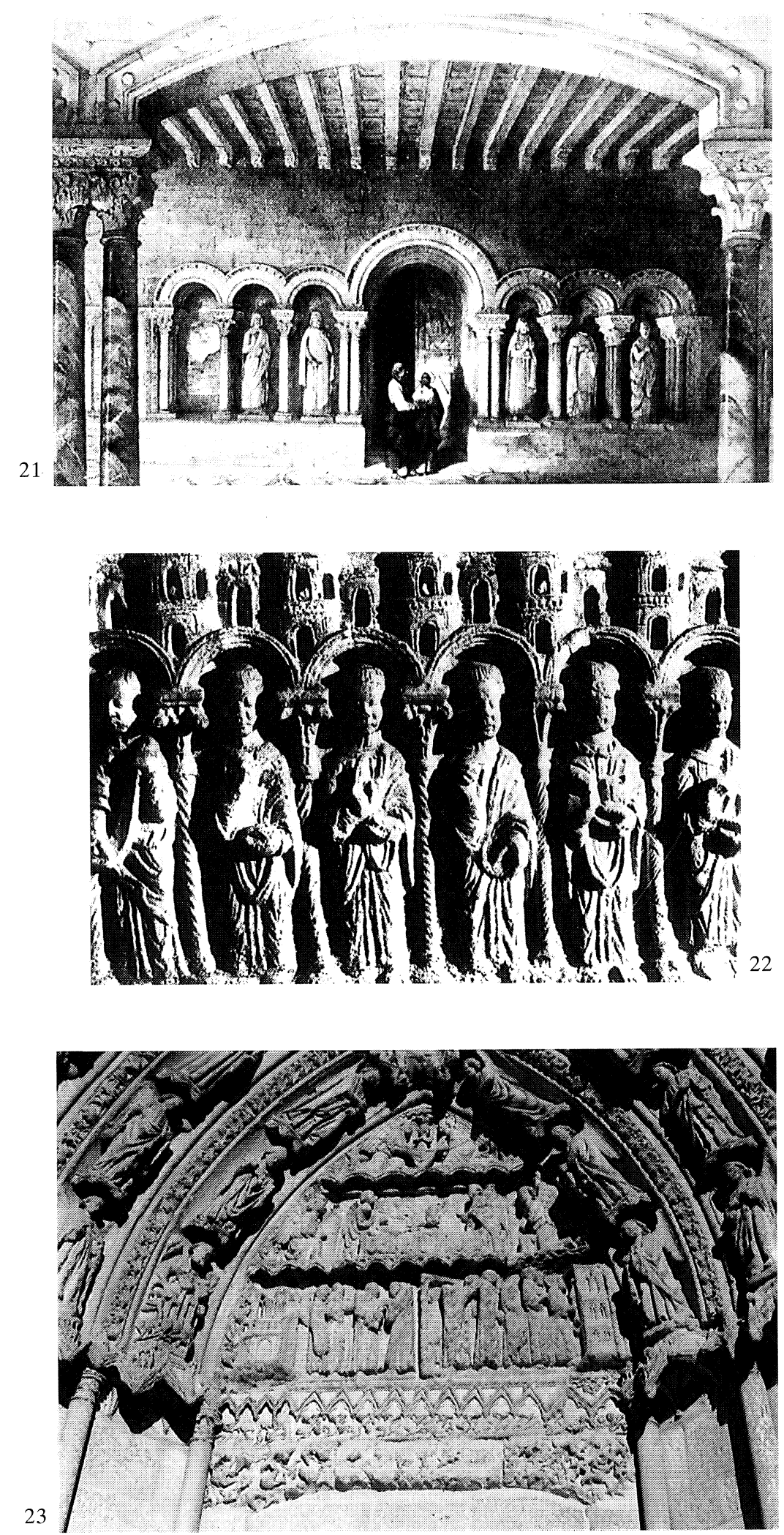

Fig. 21. Portada de la sala capitular del monasterio de Santa María de Benevívere, según un grabado de G. Pérez Villamil.

Fig. 22. Apostolado. Cenotafio de San Juan de Ortega. Iglesia parroquial de San Juan de Ortega (Burgos). (Foto tomada de J. Valdivieso Ausin, San Juan de Ortega).

Fig. 23. Portada sur de la catedral de León. En el dintel, el traslado de las reliquias de San Froilán. (Foto: autora). 


\section{Regula apostolica, norma communis}

Los relieves de San Pedro y San Pablo en el claustro leonés vienen a sumarse a la larga serie de imágenes apostólicas que en los claustros románicos y del primer gótico evocaban la vita apostolica como modelo ideal de la vita communis, encarnando de un modo plástico el tópico convertido en prescripción en la Regla de San Benito, repetido en la literatura de la reforma gregoriana y retomado posteriormente por Bernardo de Clairvaux o Abelardo ${ }^{38}$. De las múltiples formulaciones plásticas que adquirió esta idea en el arte medieval, en León parecen expresarse tanto en la indumentaria monacal de S. Pedro como en la relación establecida entre los discípulos de Cristo y los cabezas de la iglesia leonesa.

En efecto el San Pedro leonés, barbado y con las llaves en la mano, con el característico capuchón de monje, más parece un canónigo que un papa (Fig. 18). En territorio castellano-leonés este tipo de imagen parece surgir en torno al $1200{ }^{39}$. Como paralelo coetáneo cabría señalar el apostolado figurado en el cenotafio de San Juan de Ortega, donde el hábito monástico y la tonsura se extiende a todo el colegio apostólico, equiparándolo con una comunidad religiosa (Fig. 22) ${ }^{40}$.

La imagen de Pablo, representativa de este mismo ideal desde antiguo en territorio hispano, presenta una iconografía innovadora en el panorama del arte leonés ${ }^{41}$. Calvo y barbado sostiene con su derecha una cartela desenrrollada, y con la izquierda sujeta la espada mientras señala con

38 Series de apóstoles fueron labradas en las jambas de la portada de la sala capitular de San Esteban de Toulouse, en las arcadas de la canónica de Saint-Donat-sur-l'Herbasse en el valle del Ródano, o en las estatuas-columna del claustro de Notre-Dame-en-Vaux de Châlons-sur-Marne. Cfr. L. Pressouyre «Saint Bernard to Saint Francis: Monastic Ideals and Iconographic Programs in the Cloister", Romanesque and Gothic Art. Studies in Western Art. Acts of the Twentieth International Congress of the History of Art, Princeton, 1963, pp. 71-85, espec. p. 74; L. Seidel, "A Romantic Forgery: the Romanesque 'Portal' of Saint-Etienne in Toulouse", The Art Bulletin, L (1968), pp. 33-44. Para el destruído claustro de SaintDonat-sur-l'Herbasse, cfr. H. A. von Stockhausen, "Die romnischen Kreuzgänge der Provence, II. Die Plastik», Marburger Jahrbuch für kunstwissenschaft, VIII-IX, (1935), pp. 89-171, espec. p. 147, nota 7. Como precedente ya clásico para estas figuras cabe citar el apostolado de los pilares del claustro de Moissac, cfr. M. Schapiro «La escultura románica en Moissac", Estudios sobre el románico, Madrid, 1985 (1ª ed. 1932), espec. pp. 163-177. Cfr. también Ilene H. Forsyth, «The Vita Apostolica and Romanesque Sculpture», Gesta, XXV, 1 (1986) pp. 75-82.

39 La iconografía de Pedro como monje es novedad en territorio leonés en donde habitualmente se lo representa como obispo o papa. Baste citar el relieve del apóstol de la Puerta del Perdón de San Isidoro, o la magnífica estatua columna que los representa en el Pórtico de la Gloria de la catedral compostelana. Cfr. A. Viñayo, La Colegiata de San Isidoro de León, fig. 37. Se conocen representaciones medievales de Pedro con capa y capucha, como un simple monje (Vézelay), y otras en las que el apóstol aparece sin barba y tonsurado, identificándolo con las prácticas medievales de los clérigos (vidrieras de Chartres, diversas miniaturas). Cfr. C. K. Carr, Aspects on the Iconography of Saint Peter in medieval art of Western Europe to the early thirteenth century, Case Western Reserve University, 1978, pp. 11-12, 30-32, fig. 8O; y E. Male, L'art religieux du XIIème siècle, París, 1922, p. 252.

40 Para el cenotafio de San Juan de Ortega, cfr. J. Pérez Carmona, Arquitectura y escultura románicas en la provincia de Burgos, Burgos, 1975, pp. 222-223; R. Sánchez, Investigaciones Iconográficas, pp. 144-146, y 228-229. Otro ejemplo de la misma idea, formulada 'geometrico more' se encuentra en un capitel procedente del claustro del monasterio de Sahagún que se conserva hoy en en el Museo de San Marcos de León. La estrecha cohesión entre los ocho apóstoles que se disponen radialmente con respecto al cesto del capitel ofrece una síntesis plástica de la misión apostólica y de la vida comunitaria. Una reproducción del mismo en F. Llamazares, Museos, p. 50. Un paralelo para esta solución en una columna procedente de Savigny, con los apóstoles agrupados alrededror del capitel y del fuste. Cfr. D. Cateland Devos, "Sculpture de L'Abbaye de Savigny-en-Lyonnais du Haut Moyen Age au XVe siècle», Bulletin archéologique du comité des travaux historiques et scientifiques, n. s. vil (1971), pp. 151-201, espec. pp. 169-70.

41 Ya M. Schapiro señalaba la importancia concedida a San Pablo en los pilares del claustro silense, representado, anacrónicamente en los tres relieves que mostraban la asamblea de los discípulos (la Duda de Tomás, la Ascensión y Pentecostés), cfr. M. Schapiro, «Del mozárabe al románico en Silos», Estudios sobre el Románico, pp. 37-119, espec. pp. 62. Cfr. también O. K. Werkmeister, "The Emmaus and Thomas Pillars of the Cloister of Silos", Actas del Simposio "El románico en Silos», Burgos, 25-29 de septiembre de 1988, Santo Domingo de Silos, 1990, pp. 156-159 pone en relación el énfasis en la presencia de Pablo con su carácter ejemplar para la comunidad monástica, y señala como en la Vita Dominici Siliensis se reproducen pasajes de las Cartas primera y segunda a los Gálatas, para establecer un paralelo entre la vida del santo castellano y la del apóstol de los gentiles. 
el índice el desaparecido texto del pergamino (Fig. 19). La iconografía del apóstol como mártir implica el conocimiento de modelos provenientes del arte 1200 de la Isla de Francia, e invita a retardar su fecha hasta 1210-1215 42, fórmulas que se repetirán en Sahagún, en donde la inscripción de la cartela del apóstol de los gentiles «frates videte quomodo abuletis» (Gálatas, 5:15) -insiste en la referencia a la vida contemplativa, la peregrinatio in stabilitate, de acuerdo con los ideales de la vida claustral ${ }^{43}$.

En este contexto la presencia de Froilán adquiere un nuevo significado en el conjunto capitular leonés. Por entonces se le consideraba el primer reformador de la diócesis. La Vita Sancti Froilani Episcopi afirmaba que tras haber construído los monasterios de Tábara y Moreruela "sub Regula sanctae disciplina constitutas", habría establecido esta última en la sede leonesa, situada por entonces fuera de los límites de la ciudad bajo la advocación de San Pedro ${ }^{44}$. El pasaje no especifica en absoluto que Froilán estableciese una reforma canonical sujetándose a la regla agustiniana, por lo demás impensable en los reinos oocidentales de la península en aquellas fechas. Con todo parece haber constituído en comunidad monástica al clero de la catedral. En algunos documentos contemporáneos se alude al cabildo de León como «monachorum», «monachis et clericis», y "monachorum vel servos dei» 45 ; y en el año 995, trasladada la sede al interior del recinto amurallado, se cita la "Regula Sanctae Mariae» «intus cive muro Legionense» ${ }^{46}$.

Efigies de prelados reformadores eran habituales en los claustros. Baste recordar los pilares del abad Durando en Moissac o de la abadesa Renilde en Hohenburg, o el capitel con el obispo Ariberto en el claustro de Sant'Orso de Aosta ${ }^{47}$. Como también lo era la asociación de la figura de Pedro con el prelado reformador o el santo fundador de una orden. En Montmajour y Neuwiller San Pedro y San Benito compartían pilares de ángulo, y en el claustro de Aosta el apóstol acompañaba al obispo reformador Ariberto, como en León lo hace con Froilán. La primitiva dedicación apostólica de ambas iglesias no basta para justificar semejantes parejas. Como ha señalado L. Pressouyre para las escenas en que el apóstol aparecía junto a San Benito, Pedro actuaba, en estos casos, como garante de la fidelidad de la Regla a los ideales de Cristo ${ }^{48}$. La inu-

42 La más antigua representación conocida del apóstol con la espada con que fue decapitado se encuentra en una de las jambas del portal central de la fachada sur de la catedral de Chartres. Cfr. W. Sauerlander, La Sculpture gothique, lams. 110-111, pp. 112-113.

43 Cfr. R. Steven Janke, "Two Statue Columns», p. 177. Cfr. también I. Forsyth, "Vita Apostolica», espec. p. 79. Para la idea de la peregrinación interior, y el proceso de interiorización progresiva de la espiritualidad religiosa en el siglo xII, cfr. G. Constable, "Opposition to Pilgrimage in the Middle Ages", Mélanges G. Fransen I. Studia Gratiana, XIX (1976) pp. $125-146$

44 Cfr. Vita Sancti Froilani Episcopi, en A, Franco, Escultura Gótica, pp. 629-631, espec. p. 630. La noticia de la primitiva advocación de la sede legionense a San Pedro la proporciona el Tudense, al hablar de la construcción de la catedral bajo el patrocinio de Ordoño II, «(y) a la bienaventurada Virgen María..., de su propio palacio fizo fazer yglesia y estableció en ella cátedra obispal, la qual de primero era pequeña diocesis, allende de los muros de lacibdad, en honrra de Sant Pedro Apostol». Cfr. Crónica de España, ed. cit., p. 307.

45 Cfr. A. Linage Conde, “Vida canonical en la "repoblación» de la península Ibérica?», "Secundum Regulam vivere». Festchrift für P. Norbert Backmund, O. Praem herausgegeben von Gert Melville, Windberg, 1978, pp. 73-85; idem, «El Medioevo canonical en el península ibérica. Estado y perspectiva de la cuestión (1959-1983)», Santo Martino, pp. $263-278$.

46 Cfr. Risco, España sagrada, XXXIV, p. 302. El documento, en el Tumbo, fol. 311.

47 Cfr. L. Pressouyre, «St. Bernard to Saint Francis», pp. 72-73, fig. 4. Para el capitel del claustro de Aosta, cfr. A. K. Porter, Lombard Architecture, II, p. 58 y R. Berton, I Capitelli del chiostro di Sant'Orso, Novara, 1956, pp. 92-93. Para el ejemplo alsaciano, Alsace Romane, (Zodiaque, La Nuit des Temps) La Pierre-qui-vire, 1965, figs. 137-139, pp. 308-312. Para el conocido pilar de Moissac, M. Schapiro, "La escultura románica de Moissac», Estudios, pp. 153-306, espec. pp. 165-166, figs. 57, 73. También en tres claustros catalanes existieron representaciones de prelados reformadores labrados en pilastras. En Cuxá y en Ripoll, cfr. X. Barral i Altet, "La sculpture à Ripoll au XIIe siècle», Bulletin Monumental, 131, (1973) pp. 311-359, espec. p. 359, fig. 30; y en el claustro de Solsona, cfr. S. Moralejo, «De Sant Esteve de Tolosa a la Daurade", p. 112, fig. 7.

48 Cfr. L. Pressouyre, "St. Bernard to St. Francis», pp. 72-74. Cfr. también F. Benoit, L'Abbaye de Montmajour, París, 1928, p. 57 y R. Will, Repertoire de la sculpture romane de l'Alsace, Estrasburgo, París, 1955, pp. 35 y 80, fig. XVII. 
sual caracterización leonesa del apóstol como canónigo anteriormente reseñada podría ser interpretada en este sentido. De hecho la idea de Pedro como garante de la Regla debía formar parte del imaginario leonés de la época: al tiempo que se proyectaba el programa capitular escribía santo Martino de León su Veteris ac Novi Testamenti Concordia, un compendio de autoridades para la formación del clero, para la que hubo de buscar inspiración en De fide ad Petrum seu de regula verae fidei, de Fulgencio de Ruspe ${ }^{49}$. Y en efecto, ante la visión del Salvador entronizado señalando en su libro, flanqueado por Pedro y Pablo en las jambas, y acompañados por los obispos santos Froilán y Alvito cabría evocar la glosa de tópicos paulinos que el santo canónigo leonés incluye en su Sermo in dedicatione ecclesia II: "Norma igitur apostolica institutionis ambit columnas utramque, cum doctor judaeis vel gentibus predicare missus, ea tantum curat facere et docere quae per apostolos accepit et dedicit ab Ecclesia» 50.

Aunque en la segunda mitad del siglo xII, al ser secularizado el clero, los canónigos que no quisieron renunciar a su condición de monjes ocuparon el monasterio de San Isidoro, que les donó doña Sancha, hermana del emperador Alfonso VII 51, la construcción de un nuevo refectorio y una sala capitular en el claustro de la catedral leonesa inclinan a suponer un intento de restauración de la vida comunitaria en el cabildo de la catedral, y la inclusión de Froilán, el instaurador de la vida comunitaria en la sede, en el programa iconográfico de la portada del capítulo, habría de responder a estas intenciones.

Los testimonios documentales y arqueológicos permiten afirmar la existencia de un más que modesto programa escultórico en la sala capitular del claustro de la catedral de León labrado en torno al año 1200. Durante toda la primera mitad del siglo XIII el claustro se vio enriquecido con otra portada esculpida, la del refectorio, y con un conjunto de sepulcros monumentales cuyos restos se reparten hoy día entre el actual claustro y el Museo catedralicio ${ }^{52}$. Y se sabe también que con anterioridad a 1245 se habían construído en él dos capillas -la de San Nicolás y la de la Trinidad- ${ }^{53}$.

La recuperación para la historia del arte medieval castellano-leonés de este programa decorativo del primer gótico altera el panorama de la evolución del claustro medieval en Castilla y León. A pesar de la diferencia de envergadura, y de la independencia de las soluciones tipológicas, el programa monumental del claustro leonés, junto con el de Sahagún conforman una tradición que contribuye a explicar el extraordinario desarrollo decorativo alcanzado en el célebre programa burgalés de la segunda mitad del siglo.

49 Cfr. L. Robles Carcedo, «Fuentes del pensamiento teológico de Santo Martino», Santo Martino, pp. 599-622, espec. p. 611.

50 P. L., CCVIII, col. 249.

51 Cfr. A. Linage, «El monacato», p. 270 y T. Villacorta, El cabildo de la catedral de León. Estudio histórico-jurídico. Siglos XII-XIX, León, 1974.

52 Cfr. R. Sánchez, Investigaciones iconográficas, passim.

53 Para los testimonios documentales sobre las capillas del claustro, y la portada del refectorio, cfr. J. M. Ruiz Asencio, Colección Documental del Archivo de la catedral de León, VIII (1230-1269), León, 1993, pp. 142-143, 170 y 171. 